\title{
Exchanging knowledge within a community of practice: toward an epistemology of practice in Occupational Therapy paediatric hospital care ${ }^{1}$
}

\author{
Sandra Maria Galheigo ${ }^{a}$, Claudia Pellegrini Braga ${ }^{a}$, Fernanda Stella Risseto Mieto ${ }^{a}$, \\ Fernanda Viotti Parreira ${ }^{\mathrm{b}}$, Gabrielle Quintiliano Sarmento ${ }^{c}$, Margareth Motta ${ }^{\mathrm{d}}$, \\ Marianne Campopiano Abraháo Silva ${ }^{e}$, Mirella Ferreira Santos ${ }^{f}$, Priscilla Feres Spinola ${ }^{g}$, \\ Raquel Beatriz Lima Serpa ${ }^{\mathrm{h}}$, Rosa Maria de Araújo Mitrei, Thais dos Reis Olher Lagôa \\ Thelma Almir Oliveira ${ }^{j}$, Walkyria de Almeida Santos ${ }^{k}$, Lilian Magalháes', \\ Elizabeth Anne Kinsellam
}

aDepartamento de Fisioterapia, Fonoaudiologia e Terapia Ocupacional, Faculdade de Medicina, Universidade de São Paulo - USP, São Paulo, SP, Brazil.

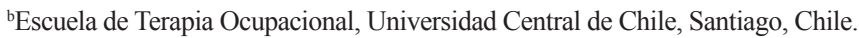

'Projeto Atendimento Multiprofissional Especializado Ação Inclusa - AMEI, Núcleo de Apoio Pedagógico

Especializado, Secretaria de Educação do Estado de São Paulo, São Paulo, SP, Brazil.

¿Hospital de Aeronáutica de São Paulo, São Paulo, SP, Brazil.

'Hospital Beneficência Portuguesa de São Paulo, São Paulo, SP, Brazil.

${ }^{\mathrm{f}}$ Hospital Santa Marcelina, São Paulo, SP, Brazil.

${ }^{\text {g} C e n t r o ~ d e ~ A t e n c ̧ a ̃ o ~ P s i c o s s o c i a l ~ A ́ l c o o l ~ e ~ D r o g a s ~ A n t o n i o ~ O r l a n d o, ~ C a m p i n a s, ~ S P, ~ B r a z i l . ~}$

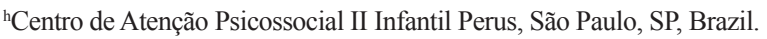

IInstituto Nacional de Saúde da Mulher, da Criança e do Adolescente Fernandes Figueira - IFF, Fundação Oswaldo Cruz - FIOCRUZ, Rio de Janeiro, RJ, Brazil.

${ }^{j}$ Centro Universitário São Camilo, Hospital Geral de Carapicuíba, São Paulo, SP, Brazil.

${ }^{k}$ Instituto de Oncologia Pediátrica - GRAACC, São Paulo, SP, Brazil.

'Departamento de Terapia Ocupacional, Universidade Federal de São Carlos - UFSCar, São Carlos, SP, Brazil.

${ }^{\mathrm{m}}$ School of Occupational Therapy, Faculty of Health Sciences, University of Western Ontário, London, ON, Canada.

\begin{abstract}
Objective: This research proposed the creation of a community of practice (CoP) with the objective of: (i) analysing the feasibility of a CoP as a means of generating knowledge among occupational therapists and (ii) investigating the practice of occupational therapy with hospitalized children and adolescents. This article privileges the results of one of the predominantly discussed themes - the use of assessments and strategies of evaluation in Occupational Therapy in the hospital context. Method: A participatory action research study was undertaken with nine occupational therapists in face-to-face meetings combined with virtual tasks on an on-line platform. A hermeneutic and dialectical method was used to interpret the results. Results: The CoP produced practical knowledge about the use of assessments with hospitalized children and adolescents and demonstrated to be a strategy of knowledge development through dialogue and collaborative reflection on practice. Conclusion: Research on the implementation of communities of practice offers a promising approach to the production of knowledge in occupational therapy. The generated knowledge is representative of occupational therapists' experiences and demonstrates an example of an epistemology of practice.
\end{abstract}

Keywords: Occupational Therapy, Hospital Care, Health Knowledge, Attitudes, Practice, Needs Assessment, Child Hospitalized.

Corresponding author: Sandra Maria Galheigo, Departamento de Fisioterapia, Fonoaudiologia e Terapia Ocupacional, Rua Cipotânea, 51, Cidade Universitária, CEP 05508-900, São Paulo, SP, Brazil, e-mail: sandramg@usp.br

Received on Feb. 20, 2017; $1^{\text {st }}$ Revision on May 29, 2017; Accepted on June 16, 2017. 


\title{
Compartilhando conhecimento em uma comunidade de prática: para uma epistemologia de prática da Terapia Ocupacional no cuidado hospitalar pediátrico
}

\begin{abstract}
Resumo: Objetivo: Esta pesquisa propôs a criação de uma comunidade de prática (CoP) com o objetivo de: (i) analisar a viabilidade de uma CoP como meio de gerar conhecimento entre terapeutas ocupacionais e (ii) investigar a prática da terapia ocupacional com crianças e adolescentes hospitalizados. Este artigo privilegia os resultados de um dos temas predominantemente discutidos - o uso de instrumentos e estratégias de avaliação em terapia ocupacional no contexto hospitalar pediátrico. Método: Foi realizada uma pesquisa-ação participativa com nove terapeutas ocupacionais em encontros face a face combinados com tarefas virtuais em uma plataforma online. Um método hermenêutico e dialético foi utilizado para interpretar os resultados. Resultados: A CoP produziu conhecimento prático sobre o uso de avaliações com crianças e adolescentes hospitalizados e demonstrou ser uma estratégia de desenvolvimento do conhecimento através do diálogo e da reflexão colaborativa sobre a prática. Conclusão: A pesquisa sobre a implementação de CoP oferece uma abordagem promissora para a produção de conhecimento em terapia ocupacional. O conhecimento gerado é representativo das experiências dos terapeutas ocupacionais e demonstra um exemplo de epistemologia da prática.
\end{abstract}

Palavras-chave: Terapia Ocupacional, Assistência Hospitalar, Conhecimento, Atitude e Práticas em Saúde, Determinação de Necessidades de Cuidados de Saúde, Criança Hospitalizada.

\section{Introduction}

Occupational therapy practice in hospital settings has increasingly changed its profile in recent decades. Todays' hospitals have gradually become a provider of short-term and intensive technological interventions. From the establishment of the profession when occupational therapists worked with long-term physically and mentally ill hospitalized patients (HOPKINS; SMITH, 1978), to the specialized contemporary hospitals they work in today, there is a substantial difference. A swift de-hospitalisation process is also under way; the growth of lifesaving technologies has been matched by the rise of outpatient procedures, leading to a decline in admissions. Further, the growing demand for post-hospitalisation assistance for patients with chronic diseases has been increasingly allocated to home-based care and outpatients' service models (PETHYBRIDGE, 2004; BRASIL, 2012).

Contemporary hospital settings have brought important challenges for occupational therapists regarding the way they envision their roles and make sense of what occupational therapy has to offer to inpatients' care. Some of these challenges were reported in a research project involving twenty-five occupational therapists working in hospitals in São Paulo, Brazil (GALHEIGO; TESSUTO, 2010). In that study, participants asserted the value of occupational therapy in hospital settings; highlighted how dynamic this field of practice was, and showed no regret for choosing this area of practice. However, the participants overwhelmingly reported a sense of professional isolation and a lack of scientific material to support their practices, pointing out a need for theoretical and technical support. Participants also discussed disparities between knowledge produced in academic contexts and the so-called reality of practice which is lived by practitioners. The participants in the Galheigo and Tessuto study often felt more comfortable explaining their roles in hospitals by means of storytelling as opposed to reference to theoretical frameworks - a result consistent with other practice-based research (MATTINGLY, 1998, p. 5-6).

[...] occupational therapists tell stories to their clients and cohorts as part of their everyday efforts to get things done. Stories have many purposes in their work lives. They tell stories of clinical experiences, their own or others, to entertain, to gossip, to confess, to argue, to reveal who they are. Often, they tell stories, especially about work experiences which are puzzling, powerful or disturbing in order to render those experiences more sensible. Storytelling offers one way to make sense of what has happened and this makes stories essential to practice.

In order to address these theory-practice challenges, a research project was developed. The project involved the creation of a Community of Practice (CoP) as proposed by Wenger (1998), with the aim to: (i) analyze the feasibility of a CoP as a means of knowledge generation amongst practicing 
occupational therapists and, (ii) investigate how front-line practitioners shared knowledge about approaches to occupational therapy practice with hospitalized children and adolescents.

The main assumption of the project was that a $\mathrm{CoP}$ could serve as a strategy for occupational therapists to share reflections and to collaboratively develop knowledge from their practice experiences. This paper focuses on the knowledge actually produced by the participants through processes of reflection and dialogue. To ground the results in practice issues, the paper focuses particularly on findings related to one of the topics discussed in the CoP - assessing hospitalized children and adolescents.

Assessment is considered as the first phase of occupational therapy intervention, but it can also be performed throughout the whole process, from gathering initial information to evaluating outcomes. Assessment involves clinical reasoning and encompasses multiple methods of data collection and interpretation, as well as providing the baseline for therapy and enabling discharge planning (FAWCETT, 2013). Context is crucial in determining why, which type, and how the assessments are to be performed (CASE-SMITH; O’BRIEN, 2013).

\section{Literature Review}

A review of the literature points to disparities between the ideals of practice as seen by occupational therapists, and the realities that the acute care setting practitioners face in daily practice (GRIFFIN; MCCONNELL, 2001). Occupational therapists have also indicated that hospital work environments tend to favour reductionist practices that are in tension with the profession's commitment to holistic and person-centred approaches and values (ROBERTSON; FINLAY, 2007).

Occupational therapists' views about their work in hospitals frequently express concerns about being devalued or disregarded by the other members of the health team, and a lack of understanding about their professional roles (ATWAL, 2002; GALHEIGO; TESSUTO, 2010; GRIFFIN; MCCONNELL, 2001; ROBERTSON; FINLAY, 2007).

Wilding and Whiteford $(2007,2008)$ have also noted occupational therapists' difficulties in explaining their unique and valuable contributions in hospital contexts. They suggest that clinical decision-making in such settings is a complex matter that requires the capacity to integrate knowledge, experience, and context. Thus, practitioners, according to Polanyi (1967, p. 4), "know more than we can tell". Practitioners make frequent use of tacit knowledge to deal with daily practical problems, and consequently find it difficult to explain what they usually do. Argyris and Schön (1992) contend that tacit knowledge is useful for understanding practitioners' theories-in-use; what they truly do, which may be distinct from their explicit knowledge, or what they say they do. According to these authors, each professional develops her own theory of practice, whether consciously or not. This theory is comprised of both tacit and explicit forms of knowledge. Argyris and Schön (1992) suggest that becoming aware of, or making explicit, practitioners' tacit understandings and frameworks may expand their possibilities for action, leaving them free to test their own theories.

In terms of knowledge production in professional practice, Donald Schön $(1983,1987)$ posits that practitioners develop professional knowledge through reflection in and on experience - what he refers to as 'epistemologies of practice'. He critiques the excessive emphasis on technical rationality, arguing that it offers an incomplete vision of what comprises professional knowledge, and calls for greater attention to the knowledge professionals generate through reflection-in and reflection-on professional practice itself. Schön (1983, p. 49) writes:

If the model of Technical Rationality is incomplete, in that it fails to account for practical competence in 'divergent' situations, so much the worse for the model. Let us search instead for an epistemology of practice implicit in the artistic, intuitive processes which some practitioners do bring to situations of uncertainty, instability, uniqueness and value conflict.

If one considers professional knowledge as comprised of both technical knowledge and epistemologies of practice (KINSELLA, 2007a, 2007b), the potential for communities of practice (WENGER, 1998) to serve as vehicles for knowledge generation in occupational therapy becomes of interest.

In this regard, communities of practice have been identified as a means to promote reflexive knowledge development among occupational therapists (KINSELLA; WHITEFORD, 2009). Communities of practice have been seen to contribute to therapists' capacities to collaboratively engage in reflection and dialogue, to articulate the value of their profession and to become more reflexive about their knowledge practices (DERDALL; MULHOLLAND; BROWN, 2010; HOFFMANN; DESHA; VERRALL, 2011; WILDING; CURTIN; 
WHITEFORD, 2012; WILDING; WHITEFORD, 2007, 2009; WIMPENNY et al., 2010).

The rise of awareness about what is tacitly produced in professional practice may also contribute to capacities to explain what occupational therapy is to others. Further, $\mathrm{CoP}$ theories contend that knowledge is not an individual possession and professional practice is not exclusively under the scrutiny of individual practitioners. Transforming practices and producing knowledge are seen as collective endeavours that imply a critical dialogue with social, historical, and discursive dimensions in which knowledge and practice are embedded.

\section{Methods}

As mentioned earlier, CoP can be combined with participatory action research projects to produce knowledge (DERDALL; MULHOLLAND; BROWN, 2010; WILDING; CURTIN; WHITEFORD, 2012; WILDING; WHITEFORD, 2007, 2009). A CoP involving paediatric occupational therapists working in hospital care was created and carried out over a seven-month period. The project had ethical clearance by the Medical School of the University of São Paulo, no 402/10 in 15/12/2010. Purposeful sampling was used. Eleven occupational therapists, all women, who worked with hospitalized children or youth at hospitals in São Paulo, Brazil, were recruited to the study through information provided by professional network. Two participants withdrew at the outset citing difficulty reconciling the after-work meetings with health or family concerns. Among the remaining nine participants, two were in their fifties, four in their thirties and three in their twenties. Three worked in general hospitals in which young people could be an occasional clientele; three in general children's hospitals; one in a burn unit; two in paediatric oncology. Their levels of experience varied: two had between 25 and 30 years of professional experience; three between 5 and 10 years and four participants up to 5 years.

All participants worked in hospitals publicly funded by the Brazilian health system. The hospitals they work in offered different levels of complexity in terms of interventions and clinical decision-making. That is, participants either worked in local/community hospitals that provide care of low to moderate complexity (4 participants); or specialized university research-intensive hospitals, which provide highly complex interventions (5 participants).

The Brazilian context encompasses a unique situation given that it is the only universal and free health system in the world with a population over 200,000,000 inhabitants (SANTOS; CAMPOS, 2015). As a relatively new system, created two decades ago, it still faces significant challenges to provide equal, sufficient, and efficient healthcare. In addition, it combines the need to offer highly complex interventions with the demands caused by extreme social vulnerability (SENNA; COSTA; SILVA, 2012). Rapid hospital discharge, although largely implemented, is not always feasible due to the precariousness of many children and teenagers' living conditions. Instances of reduced parental care often require the creation of special network assistance strategies after hospital discharge.

Participatory action research implies not only participation but a commitment to action (THIOLLENT, 1987). Therefore, the research aimed to address the interests of the participants and provide democratic conditions for their engagement.

Nonetheless, in our experience, this was not a taken-for-granted practice; participative approaches needed to be encouraged while new roles were gradually exercised across the meetings. Thus, the CoP was composed of thirteen members: two main researchers, who were in charge of the submission of the proposal for the Ethics Committee, the organization of the research activities, and the data analysis; nine practitioners-researchers who were engaged in the proposed activities; and two students who provided practical support for activities (ie. organizing meetings) of the research. A national research adviser who took part in some activities was also an eventual member of the CoP. Two international advisers who visited Brazil to meet with the CoP also contributed to data analysis and theoretical and conceptual aspects of the research.

An agreement was reached among the CoP participants at the beginning of the process concerning the ownership of the findings and their publication. Those aspects regarding the first research aim - establishing the feasibility of a $\mathrm{CoP}$ as a means of knowledge generation - would be under the responsibility of the main researchers and the ones related to the second aim - to investigate front line reports of approaches to occupational therapy practice - would be a CoP product. The participants would be invited to discuss results, and, if they were comfortable with the disclosure of their identities for dissemination purposes, to collaborate on publications.

Therefore, this article stands as a $\mathrm{CoP}$ product and is authored by all of the CoP participants and its consultants. Data was first analysed by the main researchers, then presented and discussed with the 
participants, in face-to-face meetings and, virtually, in eight on-line discussions. Further insights were garnered in discussion with the national adviser, who contributed to the understanding of aspects of the $\mathrm{CoP}$ dynamics during data collection. The international advisers collaborated in the process of examining key emerging concepts, such as epistemologies of practice, communities of practice, reflective practices and collaborative reflection, exploring how these were applied and articulate by occupational therapists working in hospitals in the Brazilian context.

\subsection{CoP activities}

Two main activities were implemented throughout the seven-month project: a) ten face-to-face meetings and b) ongoing interactive e-learning activities provided on a virtual platform. The ten face-to-face meetings took the form of focus groups. They were recorded, filmed, and transcribed. The virtual platform was used to foster communication and offered activities such as forums, on-line discussions, blogs, exchange of literature or other material the therapists had produced. Two forums on assessments were posted in the e-learning platform.

Initially, the researchers provided a list of potential topics for discussion which were reviewed and debated by the group. This resulted in the identification of the following topics as a focus for the CoPs: assessment and evaluation; therapeutic projects; methodologies of action; case studies; and challenging dimensions of intervention with regards to certain needs (oncology, palliative care, physical and/or psychological abuse, extreme poverty) or care settings (day-hospital, toy libraries, intensive care units). Despite this tentative outline, at the end of each meeting, the group reviewed the themes for the next according to what they regarded as most important to be discussed. Although the intention had been that sessions would focus on specific topics individually, the discussions dealt with these themes in an intertwined way, some of them being revisited over several meetings

\subsection{Data analysis}

The transcriptions of the focus groups and the material posted virtually were analysed by the primary researchers using line-by-line coding. These codes were transformed into categories and later grouped into major themes. The analysis was based on a critical hermeneutic perspective (KINSELLA, 2006) which combined: an interpretive process to comprehend the meanings expressed in the participants' accounts, attention to the intersubjective processes within the $\mathrm{CoP}$ and, a dialectical understanding of the influence of the macro-processes (MINAYO, 2002). A major theme emerging from this analysis was 'assessment' which is the focus of this paper. This theme was particularly important because short-term hospital stays require rapid assessments of inpatients' needs and occupational therapists must develop strategies to deal with the complexity and variety of cases and conditions they face daily. Also, therapists have a short window of opportunity to make decisions and provide interventions because discharge may happen in a rather unpredictable short period of time. Although the term assessment is the one that best fits what was discussed, it is used here in a broad sense, i.e. as data collection related to the client's needs regarding occupational therapy intervention.

\section{Results: Knowledge on Assessments Produced by the Participants}

The following presentation of results aims to represent the collective knowledge generated by therapists in the CoP with respect to the actual practice of performing assessments with hospitalized children and adolescents. The dynamics of a CoP enabled us to recognise different layers of results which reflect the what and how regarding the processes of knowledge generation that took place during the various $\mathrm{CoP}$ activities.

First, we present what was discussed, i.e, the knowledge on assessments that were actually generated by the participants during face-to-face sessions and by the virtual forums. Second, we explore how processes of reflection were embedded within the CoP discussions, and contributed to the generation of knowledge from practice.

\subsection{Meeting the demands for occupational therapy intervention: defining criteria for eligibility}

All CoP participants expressed the hardship of working in hospital settings as sole (hospital or ward) occupational therapists. Everyone indicated that it was difficult to meet the demands of case assessment and to provide care; and that this difficulty required them to define strategies and prioritize actions. These issues were subject to individual interpretation; however, after organizing the perspectives expressed in the meetings, three major trends emerged in terms of how therapists grappled 
with this tension. First, therapists spoke about the need to make decisions about which assessments to undertake according to the case. For instance, as one therapist reported:

\section{It may be a child who has just been admitted, s/he is very scared, crying. So, only a friendly contact with him/her may help to identify the demand for intervention (Participant 7).}

A second strategy identified was to pre-define the services, wards or clientele who would receive occupational therapy services. A third approach identified was to briefly consider the client's needs and everyday demands but only complete full occupational therapy assessments with priority patients.

In the CoP, all the participants indicated that they analysed the needs based on direct observation, data-gathering on medical records, and case discussion with the health team. In the virtual forum, the participants indicated that the severity of the client's condition was frequently the most important identified eligibility criterion; however, a variety of other reasons were also highlighted as shown in Table 1.

\subsection{The focus of assessment: four emerging questions}

Information about the focus of OT assessment was described by participants during the focus groups. This information was reported in an interwoven manner. For instance, in the middle of a reflection or a narrative, participants indicated bits and pieces of components which they considered relevant during case assessment. Analysis of the data revealed four main issues that highlighted the focus of therapists' reasoning during assessment:

1. Who is this person and what does s/he want to do?

2. What is the child's and the family's history? What is the experience of disability or illness?

3. What kind of impact is occurring in their everyday lives and occupations?

4. What kind of support is needed and/or available?

The participants' accounts revealed that their reasoning did not take place separately question by question, but rather the topics were intertwined with one another. Below are quotations from the data that speak to the four issues that we identified as underpinning the therapists' reasoning during case assessment.

We get there seeking to know what they enjoy doing, their opportunities in the world, what this child would like to be doing (Participant 3).

We get there and somehow ask: Who are you truly? What do you do? What do you mostly miss? What are you doing here? How can we help you? Do you need to adapt anything? [...] The institution [the hospital] is designed to break it [their daily life], it does break it and our work is a delicate work of rebuilding it (Participant 4).

We are different from the other professionals. It is the rapport... how I get there, how I hear... we do not focus on disease. Our focus is on something else... the wellbeing, what hospitalization means to his/her. Other professionals go there and ask

Table 1. Eligibility criteria for occupational therapy services.

\begin{tabular}{|c|c|c|}
\hline \multicolumn{3}{|c|}{ Eligibility criteria } \\
\hline $\begin{array}{l}\text { Regarding the process of } \\
\text { becoming ill, being under } \\
\text { treatment and hospitalized }\end{array}$ & $\begin{array}{l}\text { Developmental, emotional \& } \\
\text { social repercussions }\end{array}$ & $\begin{array}{l}\text { Regarding disruption in daily life } \\
\text { \& occupation }\end{array}$ \\
\hline - severity of the client's condition; & $\begin{array}{l}\text { - becoming emotionally detached } \\
\text { from family \& social context; }\end{array}$ & - need for assistive technology; \\
\hline - first hospital stay; & - showing signs of depression; & - lack of autonomy/agency; \\
\hline - long-term hospitalization; & $\begin{array}{l}\text { - refusal or denial regarding the } \\
\text { illness \& treatment (by family } \\
\text { and/or patient); }\end{array}$ & $\begin{array}{l}\text { - disengagement in daily } \\
\text { occupations (such as play, going } \\
\text { to school \& others). }\end{array}$ \\
\hline $\begin{array}{l}\text { - significant change in the course } \\
\text { of the disease; }\end{array}$ & - social isolation; & \\
\hline - isolation or bed ridden; & $\begin{array}{l}\text { - difficulties in the interaction with } \\
\text { the family and other children; }\end{array}$ & \\
\hline $\begin{array}{l}\text { - pain or under palliative care; } \\
\text { - poor knowledge \& understanding } \\
\text { of the illness and/or treatment. }\end{array}$ & - developmental difficulties. & \\
\hline
\end{tabular}


"Did you eat? Drink? Take the medication? How are your symptoms?" But we seek to focus on that person as a protagonist (Participant 1).

Regarding the assessment tool, we have one for every patient based on age, development, the issue of hospitalization [...] Did the child stop going to school? How does s/he organize everyday life? [...] What are the feeding restrictions? Who is responsible for delivering medication?[...] Also, the occupational history to know interests, preferences (Participant 3).

He was so scared with everything, with the [intravenous] access; he was so young; he didn't move at all. If someone advised him, 'Hey, you should rest', he would continue to lie down the whole time, not even allowing the family to raise his head from the bed... so we thought 'well, we need to intervene' (Participant 4).

It is not a question of the disease per se, but you also need to know about it. For instance, the patient has cancer; which treatment is helshe receiving? What are the impacts on life quality? Does it cause a disruption [in everyday life]? How long is s/he to be hospitalized? Is s/he an outpatient? Is s/he under diagnostic investigation? Then you realize that there are other things at stake [...] (Participant 4).

What I see in my practice is that the [hospital] intervention leads to a greater vulnerability. When hospitalization takes place, the getting ill, the suffering, the family involvement [...] [everything] is under a magnifying glass... if the parents have relationship problems, this is magnified out of proportion (Participant 5).

(talking about children enjoying being at hospital) Sometimes the child doesn't have [toys] at home; sometimes they love [being there] for other reasons: parents do not have time to play with the child at home; when the child is hospitalized the mother and the father can pay attention to him/ her (Participant 6).

As represented in the figure below (Figure 1), analysis of the participants' responses showed how these four issues informed therapists quest to understand the lives of the children and adolescents.

Occupational therapists' responses showed their attention to children and adolescents' interests and life motivations; their life histories; how they engage in play and their level of development, as well as interest in what matters in these individuals' lives. To understand the history and experience of the client's process of health and illness, therapists indicated that they sought to obtain information both from the child and from the hospital records. Accordingly, they looked for information about the way the process of becoming ill and being hospitalized took place; the diagnosis and prognosis; the expected length of hospitalization. They also explored the clientele-specific demands for treatment and the needs for referrals and orientation after discharge.

Another point of interest was related to therapists' accounts of the impact that the process

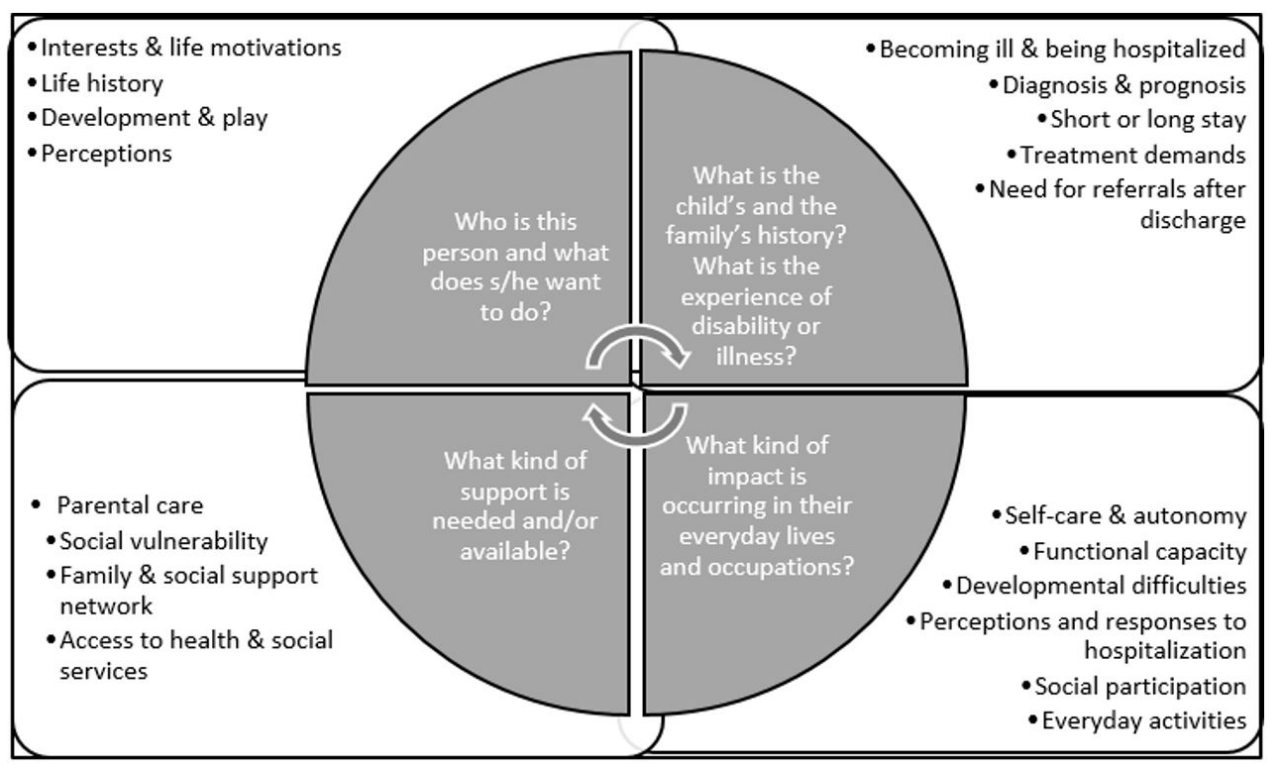

Figure 1. A context-based assessment frame. 
of becoming ill and being hospitalized had on the children and adolescents' lives in terms of self-care and autonomy; functional capacity and social participation. The occupational therapists indicated that it was important to know if becoming ill had triggered developmental difficulties, as well as to understand the perceptions the patients hold about their conditions and the way they respond to them. Finally, the participants' discussions showed that in daily practice occupational therapists were interested in knowing the kind of family and social support that hospitalized children and adolescents could count on, and in considering the possibility of these children living under a condition of social vulnerability as well as their need to further access health and social services after discharge.

\subsection{The institutional context}

Another topic that emerged in participants' discussion of assessment pointed to tensions between occupation-based and person-centred perspectives of occupational therapy versus the disease-centred approaches of hospital settings. Some therapists suggested that a disease-centred approach can work against the recognition of the person within that is central to enabling occupation and to promoting a better life quality:

At the hospital, he is not 'a person with a disease', he is 'the illness,', the diseased organ'. This generates an autobiographical disjunction for this person, doesn't it? Thus, he is not someone who plays, or the child who enjoyed playing with this or that, someone who has a baby brother or, in case of an adult, who is a lawyer or has those occupational roles, things that he does and is valued for. The kind of daily life that is kept within boundaries someone who belongs to oneself, has autonomy, is in charge. When helshe arrives at the hospital, all of this goes away (Participant 4).

Further, all of the participants expressed ethical and political commitments related to enabling people to envision their identities beyond their diseases.

I think the medical power is not the most difficult thing. I think the difficulty is being in the wrong lane' of this 'vision of health'. You are working for something else and this is against the tide. You want the child to look [at the world] in a different way. This is complicated and has nothing to do with me as a professional, or how I see things. This actually has something to do with that child, how she looks [at the world] beyond the cancer she has got (Participant 3).
In summary, all participants indicated tensions that arose from the institutional context in terms of implementing occupation-based, person-centred approaches to case assessments and were critical of the constraints placed on their work in light of a hospital care focus on disease and the biomedical model.

\section{Discussion}

The findings of the study reveal both explicit and implicit (tacit embodied) therapist knowledge through reflection and dialogue (KINSELLA; WHITEFORD, 2009) in the context of a CoP. The what and how of paediatric assessments in hospital care is a common issue for occupational therapists. Given that participants in a CoP share interests in a particular subject or concern, the specific topic of assessment in hospital care paediatric occupational therapy practice emerged as a prevalent theme. Furthermore, it is important to notice that a CoP can activate a network (FOLEY; MASINGILA, 2015). In the process of this research, existing relationships among participants were nurtured and new connections among participants were made, enabling shared reflection. Hence, practice-based knowledge that could be of practical use was shared between therapists. Thus, the study might be viewed as contributing to an epistemology of practice that can complement other assessment tools in the area of hospital care paediatric occupational therapy assessment.

\subsection{Epistemologies of practice: developing knowledge from practice}

One of the outcomes of the project was the identification of the implicit questions that therapists ask themselves as they engage in the assessment process, and the generation of a context-based assessment frame (See Figure 1). This frame may be helpful to represent the therapists' practice-based knowledge, as it derived from an analysis of the reflections and practices that the therapists articulated as occurring within their hospital care practice settings. This type of knowledge, rooted in first-hand experiences of therapists, is often implicit, and might be viewed as an epistemology of practice (SCHÖN, 1987; KINSELLA, 2009) - knowledge generated from practice experience.

The process of reflection and dialogue within the CoP may potentially serve as means of articulating, documenting and validating the 'invisible' therapist 
knowledge derived from practice experience. The development of epistemologies of practice through CoPs in occupational therapy, have the potential to contribute to the knowledge base of the profession by making practice-based knowledge explicit and therefore potentially visible and accessible to others working with children in hospital care settings.

\subsection{Critical reflection and hospital care institutional contexts}

Through the CoP, the participants could come together, share their experiences, and reflect upon their professional practice. The face-to-face meetings were important because they made dialogue possible. In an area of practice that can be isolating and challenging, due not only to the small number of occupational therapists employed in hospital settings in Brazil, but also because the continuing dominance of the biomedical model, the possibility of being heard and making collective sense of practice issues is vital for regaining one's sense of self affirmation and recognition (FRASER, 2000).

An emergent body of literature has been focusing on the power dynamics within occupational therapy practices. As Wilding (2011) points out, hegemony may be at play when occupational therapists unconsciously comply with the medical and scientific narratives that lead to "the subjugation and poor representation of the profession" (WILDING, 2011, p. 293). Further, Kinsella (2009) suggests that hegemony might be noted among occupational therapists whenever there is a lack of epistemic reflexivity, which she describes as a "[...] critical reflection on the social conditions under which our disciplinary knowledge comes into being" (KINSELLA, 2009, p. 256).

Indeed, there were a number of examples of how critical reflection about daily professional practice can be exercised with peers in a $\mathrm{CoP}$ which lead to important insights of a systemic nature. Engaging in critical reflection within communities of practice may contribute to reclaiming the importance of an occupational focus in hospital care contexts, recognition of a more complex perspective of how occupational therapy may contribute to this area of practice, and a more humanized approach to hospital practices. The therapists in this study frequently described their daily routines as working against the grain, in what might be described as anti-hegemonic activities within their working contexts. Therapists may resist the biomedical model in hospital care by working to put the client at the centre of the process, seeing the person as more than the disease, working with families and systems as well as children, working from an occupational perspective, and challenging a context that is reductionist and disease oriented. Ultimately, through a CoP, it was possible to reflect on the circumstances by which the Brazilian healthcare system shapes, hinders and/or contributes to occupational therapy hospital practices.

\section{Conclusion}

This study on communities of practice provided three different sets of results: one regarding knowledge produced by the participants on their case assessment processes with hospitalized children and adolescents. The second showed the development of practice-based knowledge through reflection and dialogue within a focused group process. Thirdly it provided an opportunity to critically reflect on tensions in enacting occupational therapy paediatric assessment within hospital care contexts.

The CoP also enabled the participants to engage in different kinds of communication forms and experience sharing. They could exchange information, complain, tell stories, reflect on their practice, and critically reflect on the functioning of the health system, the power dynamics amongst health professionals and the challenges of working from a comprehensive perspective within a biomedical model in hospital settings. This process provided the means for generation of practice knowledge that may be practical useful and has the potential to be tested, validated and to be shared with other occupational therapists.

Research on the implementation of communities of practice in occupational therapy is still in the early stages and there are few similar studies with which to compare this one. However, studies, which report epistemological tensions for occupational therapists who work in hospital settings showed similar conclusions (WILDING; WHITEFORD, 2007, 2009). Limitations of the study are that the findings are specific to a Brazilian context. Since cultural and political components play an important role in this context, the findings may not be consistent with the realities of other countries that are either affluent or resource limited in different ways.

\section{References}

ARGYRIS, C.; SCHÖN, D. Theory in practice: increasing professional effectiveness. San Francisco: Jossey-Bass, 1992.

ATWAL, A. A world apart: how occupational therapists, nurses and care managers perceive each other in acute 
health care. British Journal of Occupational Therapy, London, v. 65, n. 10, p. 446-452, 2002. http://dx.doi.org/1 $0.1177 / 030802260206501003$.

BRASIL. Ministério da Saúde. Melhor em casa: a segurança do hospital no conforto da sua casa. Brasília, 2012. (Caderno de Atenção Domiciliar, 1). Available from: <http://189.28.128.100/dab/docs/publicacoes/geral/ cad_vol1.pdf>. Access on: 18 apr 2013.

CASE-SMITH, J.; O'BRIEN, J. C. Occupational therapy for children. Maryland Heights: Mosby Elsevier, 2013.

DERDALL, M.; MULHOLLAND, S.; BROWN, C. Evaluating students' use of web-based communication during practice placements. British Journal of Occupational Therapy, London, v. 73, n. 10, p. 457460, 2010. http://dx.doi.org/10.4276/03080221 0X12865330218221.

FAWCETT, A. L. Principles of assessment and outcome measurement for occupational therapists and physiotherapists: theory, skills and application. Hoboken: John Wiley \& Sons, 2013.

FOLEY, L. A.; MASINGILA, J. O. The use of mobile devices as assistive technology in resource-limited environments: access for learners with visual impairments in Kenya. Disability and Rehabilitation: Assistive Technology, Abingdon, v. 10, n. 4, p. 332-339, 2015. PMid:25342493. http://dx.doi.org/10.3109/17483107 2014.974220 .

FRASER, N. Rethinking recognition. New Left Review, London, v. 3, p. 107-118, 2000.

GALHEIGO, S. M.; TESSUTO, L. A. Trajetórias, percepçóes e inquietaçóes de terapeutas ocupacionais do Estado de São Paulo no âmbito das práticas da terapia ocupacional no hospital. Revista de Terapia Ocupacional da USP, São Paulo, v. 21, n. 1, p. 23-32, 2010.

GRIFFIN, S.; MCCONNELL, D. Australian occupational therapy in acute care settings. Occupational Therapy International, London, v. 8, p. 184-197, 2001.

HOFFMANN, T.; DESHA, L.; VERRALL, K. Evaluating an online occupational therapy community of practice and its role in supporting occupational therapy practice. Australian Occupational Therapy Journal, Melbourne, v. 58, n. 5, p. 337-345, 2011. PMid:21957918. http://dx.doi.org/10.1111/j.1440-1630.2011.00954.x.

HOPKINS, H.; SMITH, H. Willard and Spackman's occupational therapy. Philadelphia: J. B. Lippincott Company, 1978.

KINSELLA, E. A. Hermeneutics and critical hermeneutics: exploring possibilities within the art of interpretation. Forum Qualitative Social Research, Berlin, v. 7, n. 3, 2006.

KINSELLA, E. A. Embodied reflection and the epistemology of reflective practice. Journal of Philosophy of Education, Chichester, v. 41, n. 3, p. 395-409, 2007 a. http://dx.doi.org/10.1111/j.1467-9752.2007.00574.x.
KINSELLA, E. A. Technical rationality in Schön's reflective practice: dichotomous or non-dualistic epistemological position. Nursing Philosophy, Oxford, v. 8, n. 2, p. 102-113, 2007b.

KINSELLA, E. A. Professional knowledge and the epistemology of reflective practice. Nursing Philosophy, Oxford, v. 11, n. 1, p. 3-14, 2009.

KINSELLA, E. A.; WHITEFORD, G. Knowledge generation and utilisation in occupational therapy: towards epistemic reflexivity. Australian Occupational Therapy Journal, Melbourne, v. 56, n. 4, p. 249-258, 2009. PMid:20854525. http://dx.doi.org/10.1111/j.1440-1630.2007.00726.x.

MATTINGLY, C. Healing dramas and clinical plots: the narrative structure of experience. Cambridge: Cambridge University Press, 1998.

MINAYO, M. C. Hermenêutica-dialética como caminho do pensamento social. In: MINAYO, M. C.; DESLANDES, S. Caminhos do pensamento: epistemologia e método. Rio de Janeiro: Fiocruz, 2002. p. 83-108.

PETHYBRIDGE, J. How team working influences discharge planning from hospital: a study of four multi-disciplinary teams in an acute hospital in England. Journal of Interprofessional Care, Abingdon, v. 18, n. 1, p. 29-41, 2004. PMid:14668100. http://dx.doi.org/10.1080/135 61820410001639334.

POLANYI, M. The tacit dimension. London: Routledge, 1967.

ROBERTSON, C.; FINLAY, L. Making a difference, teamwork and coping: the meaning of practice in acute physical settings. British Journal of Occupational Therapy, London, v. 70, n. 2, p. 73-80, 2007. http://dx.doi.org/1 $0.1177 / 030802260707000205$.

SANTOS, L.; CAMPOS, G. W. S. SUS Brasil: a região de saúde como caminho. Saúde e Sociedade, São Paulo, v. 24, n. 2, p. 438-446, 2015.

SCHÖN, D. The reflective practitioner: how professionals think in action. New York: Basic Books, 1983.

SCHÖN, D. Educating the reflective practitioner. San Francisco: Jossey-Bass, 1987.

SENNA, M. D. C. M.; COSTA, A. M. D.; SILVA, L. N. D. Atenção à saúde em grandes centros urbanos: desafios à consolidação do SUS. Sociedade em Debate, Pelotas, v. 16, n. 1, p. 121-137, 2012.

THIOLLENT, M. Notas para o debate sobre pesquisaação. In: BRANDÃO, C. R. Repensando a pesquisa participante. Sáo Paulo: Brasiliense, 1987. p. 82-103.

WENGER, E. Communities of practice: learning, meaning and identity. Cambridge: Cambridge University Press, 1998.

WILDING, C. Raising awareness of hegemony in occupational therapy: the value of action research for improv- 
ing practice. Australian Occupational Therapy Journal, Melbourne, v. 58, n. 4, p. 293-299, 2011. PMid:21770965. http://dx.doi.org/10.1111/j.1440-1630.2010.00910.x.

WILDING, C.; CURTIN, M.; WHITEFORD, G. Enhancing occupational therapists' confidence and professional development through a community of practice scholars. Australian Occupational Therapy Journal, Melbourne, v. 59, n. 4, p. 312-318, 2012. PMid:22934904. http://dx.doi.org/10.1111/j.1440-1630.2012.01031.x.

WILDING, C.; WHITEFORD, G. Occupation and occupational therapy: knowledge paradigms and everyday practice. Australian Occupational Therapy Journal, Melbourne, v. 54, n. 3, p. 185-193, 2007. http://dx.doi. org/10.1111/j.1440-1630.2006.00621.x.
WILDING, C.; WHITEFORD, G. Language, identity and representation: occupation and occupational therapy in acute settings. Australian Occupational Therapy Journal, Melbourne, v. 55, n. 3, p. 180-187, 2008. PMid:20887460 http://dx.doi.org/10.1111/j.1440-1630.2007.00678.x.

WILDING, C.; WHITEFORD, G. From practice to praxis: Reconnecting moral vision with philosophical underpinnings. British Journal of Occupational Therapy, London, v. 72, n. 10, p. 434-441, 2009.

WIMPENNY, K. et al. Implementing the model of human occupation across a mental health occupational therapy service: Communities of practice and a participatory change process. British Journal of Occupational Therapy, London, v. 73, n. 11, p. 507-516, 2010. http:// dx.doi.org/10.4276/030802210X12892992239152.

\section{Author's Contributions}

All authors have contributed equally and approved the final version of the text.

\section{Funding Source}

This research was made possible by the support of the São Paulo Research Foundation - FAPESP, Brazil, grant $n^{\circ}$ 2010/19718-0 and by the International Cooperation FAPESP, Brazil/Western University, Canada, grant $n$ o $2011 / 51766-8$.

\section{Notas}

${ }^{1}$ The project has ethical clearance by the Medical School of the University of São Paulo, no 402/10 in 15/12/2010. 